УДК 349.2

DOI https: / / doi.org/10.32837/yuv.v0i6.2048

\author{
С. Козін, \\ кандидат юридичних наук, \\ докторант \\ Науково-дослідного інституту публічного права
}

\title{
СУТНІСТЬ ТА ОСОБЛИВОСТІ ЗАХИСТУ ТРУДОВИХ ПРАВ МІГРАНТІВ
}

Постановка проблеми. Юридичні можливості людини на території будь-якої держави залежать від декількох факторів, серед яких слід назвати ступінь нормативного регулювання прав людини, місце права в системі регулювання суспільних відносин, а також ставлення держави до питання непорушності правового статусу людини й громадянина. На нашу думку, останній момент постає найбільш важливим, адже фактично йдеться про захист із боку держави законних інтересів кожного індивіда. Крім того, особливо гостро питання захисту юридичних можливостей постає щодо суб'єктів, які перебувають у «групі ризику», тобто їх правовий статус має складний, іноді невизначений або навіть спірний характер. Саме такими суб'єктами сьогодні є мігранти. Внаслідок особливостей свого правового статусу представники цієї соціально-правової групи потребують захисту прав, зокрема, у трудовій галузі.

Стан дослідження проблеми. В сучасній науковий площині особливості та сутність категорії захисту трудових прав мігрантів не отримали грунтовного теоретичного розроблення. Натомість багато вчених досліджували у своїх працях специфіку правового захисту в його загальному змісті, зокрема М.Ю. Тихомирова, С.С. Алексєєв, 3.В. Ромовська, B.I. Тертишніков, I.I. Лізікова, В.А. Тарасов, І.В. Лагутін, М.Г. Александров.
Мета статті полягає у з'ясуванні сутності та особливостей захисту трудових прав мігрантів.

Виклад основного матеріалу. Варто відзначити особливу дискусійність та невизначеність у науковій площині питання захисту трудових прав мігрантів, що пов'язано з поняттям та особливостями категорії «захист» у юридичній реальності загалом. Так, слово «захист» (похідне від «захищати») означає заступництво, охорону, підтримку; місце, притулок, де можна захиститись, заховатись від кого-, чого-небудь; укриття; споруду, пристосування тощо, що захищає від кого-, чого-небудь; сторону, яка захищає обвинуваченого під час суду; тих, хто у складі спортивної команди захищають якусь ділянку ігрового поля під час гри у футбол, хокей тощо [1, с. 432].

Таким чином, захист у загальнолексичному змісті - це особлива форма діяльності, спрямована на недопущення дії певного негативного фактору на щось чи когось, іншими словами, це реакція на якийсь негативний, погрожуючий чинник. При цьому, на наш погляд, некоректним $€$ ототожнення категорій «захист» та «охорона». Основу змісту обох слів становить термін дії явищ, які ними позначені. Так, охорона виражає систематичну діяльність 3 підтримки порядку або недоторканості певного об'єкта, тоді як захист має зміст реактивної, моментальної дії на якісь порушення. 


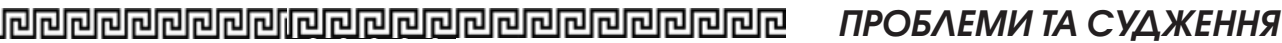

В літературі юридичної спрямованості поняття захисту тлумачиться досить неодноманітно. Наприклад, відповідно до юридичного словника М.Ю. Тихомирова, захист розуміється таким чином: по-перше, як комплексна система заходів, що застосовуються для забезпечення вільної та належної реалізації суб'єктивних прав, що включає судовий захист; законодавчі, економічні, організаційно-технічні та інші засоби й заходи, а також самозахист прав; по-друге, як право обвинуваченого або підозрюваного захищатися від обвинувачення за допомогою заяв і клопотань, використання законних прав та інших дозволених способів, а також на будь-якій стадії процесу вимагати присутності захисника [2, с. 189]. С.С. Алексєєв дотримується думки про те, що правовий захист - це державно-примусова діяльність, спрямована на поновлення порушеного права, забезпечення виконання юридичного обов'язку [3, с. 346].

На думку 3.В. Ромовської, правовий захист - це завжди акт, що вже відбувся. Іноді для реалізації заходу державного примусу достатньо винесення судового рішення. Оскільки в рішеннях про визнання права чи розірвання договору відповідач не примушується до певної активної поведінки, акт правосуддя й правовий захист збігаються у часі. Якщо ж відповідач присуджується до певної поведінки (повернути майно, сплатити неустойку), то реалізація державного примусу органічно пов'язана з виконанням рішення, без чого правовий захист не можна вважати таким, що відбувся [4, с. 347]. B.I. Тертишніков захистом права називає таке здійснення права та перетворення правовідносин, яке можливе лише за допомогою спеціального державного органу [5, с. 9].

Деякі вчені розглядали поняття правового захисту відповідно до конкретного об'єкта, в позиціях яких можна виділити раціональне зерно, корисне для побудови власної наукової думки. Наприклад, I.I. Лізікова визначає правий захист працівників нині ненаявного органу міліції таким чином: «правова захищеність працівників міліції - це гарантоване нормами права ефективне й оперативне обмеження від протиправних посягань, забезпечення законом права на захист і самозахист від неправомірних впливів на їхні права та інтереси з боку різних державних, громадських установ і організацій, а також громадян» $[6$, с. 341].

Проаналізовані підходи до розуміння поняття правового захисту дають нам можливість висунути низку висновків щодо зазначеної категорії у класичному вигляді загалом та щодо трудових прав мігрантів зокрема. Так, правовий захист має комплексний, складний характер, у зв'язку з чим ця категорії фактично «живе» одразу у трьох вимірах. Зокрема, захист можна вважати особливим режимом юридичної охорони або захищеності прав відповідних суб'єктів, в нашому випадку мігрантів, коли їх законні інтереси та можливості визначають на території держави, мають юридичне обрамлення, забезпечуються чинним законодавством, а за їх порушення передбачено відповідну форму відповідальності. Одночасно правовий захист має своєрідний активний бік, відповідно до якого це особлива система визначених законодавством заходів, засобів та методів юридичного впливу на суспільні відносини. Метою ї застосування $€$ забезпечення можливості відповідних суб'єктів реалізовувати свої права, а також притягнення до відповідальності осіб, які їх порушують або обмежують.

При цьому коли ми говоримо про захист прав мігрантів, ми не робимо акцент на якусь конкретну галузь права, оскільки категорія захисту в цьому разі має нейтральне забарвлення, у зв'язку з чим виражається одразу у декількох правових інститутах різних галузей права. 
Для доведення цієї позиції розглянемо конкретні юридичні вияви правового захисту трудових прав мігрантів. Так, варто назвати загальні норми трудового законодавства, які регламентують діяльність усіх категорій працівників. Зокрема, як і інші суб’єкти трудових відносин, іноземці мають право на гарантії своїх трудових можливостей під час прийняття на роботу. В положеннях КЗпП регламентовано порядок та особливості укладення трудових договорів. Відповідно до положень Кодексу, трудовим договором $є$ угода між працівником і власником підприємства, установи, організації або уповноваженим ним органом чи фізичною особою, за якою працівник зобов'язується виконувати роботу, визначену цією угодою, а власник підприємства, установи, організації або уповноважений ним орган чи фізична особа зобов'язується виплачувати працівникові заробітну плату й забезпечувати умови праці, необхідні для виконання роботи, передбачені законодавством про працю, колективним договором і угодою сторін. Працівник має право реалізувати свої здібності до продуктивної і творчої праці шляхом укладання трудового договору на одному або одночасно на декількох підприємствах, в установах, організаціях, якщо інше не передбачено законодавством, колективним договором або угодою сторін [7]. Момент укладання трудового договору є важливим юридичним фактом, який веде до появи як у роботодавця, так i у іноземця трудових прав та обов'язків, які ці суб'єкти в подальшому реалізують. Відповідно до статті 22 КЗпП, забороняється необгрунтована відмова у прийнятті на роботу. Будь-яке пряме або непряме обмеження прав чи встановлення прямих або непрямих переваг під час укладання, зміни та припинення трудового договору залежно від походження, соціального і майнового стану, расової та національної приналежності, статі, мови, політичних поглядів, релігійних переконань, членства у професійній спілці чи іншому об'єднанні громадян, роду і характеру занять, місця проживання не допускається [7].

Крім цього, як суб'єкти трудового права мігранти також мають юридично визначені гарантії в аспекті оплати ї праці. Відповідно до Закону України «Про оплату праці» від 24 березня 1995 р. № 108/95-ВР, всі працівники, у тому числі мігранти, отримують заробітну плату - винагороду, обчислену, як правило, у грошовому виразі, яку за трудовим договором роботодавець виплачує працівникові за виконану ним роботу. Розмір заробітної плати залежить від складності та умов виконуваної роботи, професійно-ділових якостей працівника, результатів його праці та господарської діяльності підприємства [8].

Захист трудових прав мігрантів також виражається у діяльності відповідних державних служб, які здійснюють контроль у сфері трудової діяльності. Прикладом є Державна служба з питань праці - центральний орган виконавчої влади, діяльність якого спрямовується і координується Кабінетом Міністрів України через Міністра розвитку економіки, торгівлі та сільського господарства і який реалізує державну політику у сферах промислової безпеки, охорони праці, гігієни праці, поводження 3 вибуховими матеріалами промислового призначення, здійснення державного гірничого нагляду, а також з питань нагляду та контролю за додержанням законодавства про працю, зайнятість населення, загальнообов'язкове державне соціальне страхування від нещасного випадку на виробництві та професійного захворювання, які спричинили втрату працездатності, у зв'язку з тимчасовою втратою працездатності, на випадок безробіття щодо призначення, нарахування та виплати допомоги, компенсацій, надання соціальних послуг та інших видів матеріального забезпечення

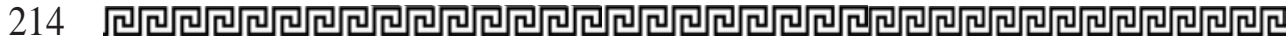


задля дотримання прав і гарантій застрахованих осіб [9]. Так, зазначений орган вживає у своїй діяльності заходів державного контролю за додержанням законодавства про працю шляхом виявлення неоформлених трудових відносин шляхом інспекційних відвідувань [10].

Таким чином, держава в особі уповноважених органів державної влади здійснює контроль у сфері праці, метою якого є забезпечення законності, а також непорушності ключових прав та свобод людини і громадянина. Зокрема, праця будь-якої особи без належного оформлення, тобто без укладання з нею трудового договору, у тому числі мігранта, $є$ серйозним порушенням трудового законодавства. Фактично така праця $€$ «тіньовою», у зв'язку з чим працівник, наприклад, іноземець, який працює на підприємстві чи в організації, не має статусу працівника, що, зрештою, може обмежити його можливості у користуванні передбаченими законодавством гарантіями у сфері праці.

Досліджуючи правовий захист трудових прав мігрантів, не можемо залишити поза увагою процедурні моменти забезпечення законних інтересів цих суб'єктів у сфері праці. Зокрема, Закон України «Про зайнятість населення» від 5 липня 2012 р. № 5067-VI говорить про те, що українські роботодавці мають право на застосування праці іноземців та осіб без громадянства на території України на підставі дозволу, що видається територіальними органами центрального органу виконавчої влади, що реалізує державну політику у сфері зайнятості населення та трудової міграції [11]. Праця іноземців можлива без дозволу, якщо такий іноземець підпадає під одну з категорій-винятків. Так, дозвіл не потрібен, якщо йдеться про працевлаштування іноземців та осіб без громадянства, які постійно проживають в Україні; іноземців та осіб без громадянства, які набули статусу біженця відповідно до законодавства
України або одержали дозвіл на імміграцію в Україну; іноземців та осіб без громадянства, яких визнано особами, що потребують додаткового захисту, або яким надано тимчасовий захист в Україні; представників іноземного морського (річкового) флоту та авіакомпаній, які обслуговують такі компанії на території України; осіб, яких визнано особами без громадянства центральним органом виконавчої влади, що реалізує державну політику у сфері міграції (імміграції та еміграціi), у тому числі протидії нелегальній (незаконній) міграції, громадянства, реєстрації фізичних осіб, біженців та інших визначених законодавством категорій мігрантів; працівників закордонних засобів масової інформаціï, акредитованих для роботи в Україні; спортсменів, які набули професійного статусу, артистів та працівників мистецтва для роботи в Україні за фахом; працівників аварійно-рятувальних служб для виконання термінових робіт; працівників іноземних представництв, які зареєстровані на території України в установленому законодавством порядку; священнослужителів, які є іноземцями і тимчасово перебувають в Україні на запрошення релігійних організацій для провадження канонічної діяльності лише у таких організаціях з офіційним погодженням з органом, який здійснив реєстрацію статуту (положення) відповідної релігійної організації; іноземців та осіб без громадянства, які прибули в Україну для участі у реалізації проєктів міжнародної технічної допомоги [11].

Крім того, роботодавець отримує дозвіл для таких категорій осіб, якщо інше не встановлено міжнародними договорами України:

1) відряджені іноземні працівники;

2) внутрішньокорпоративні цесіонаріі;

3) іноземці та особи без громадянства, стосовно яких прийнято рішення про оформлення документів для вирішення питання про визнання біженцем або особою, яка потребує додаткового захисту; 
4) особи, які подали заяву про визнання особою без громадянства, та особи, які оскаржують рішення про відмову у визнанні особою без громадянства.

Особливими категоріями іноземців та осіб без громадянства, які претендують на працевлаштування в Україні, є такі:

1) іноземні високооплачувані професіонали;

2) засновники та/або учасники, та/або бенефіціари (контролери) юридичної особи, створеної в Україні;

3) випускники університетів, що входять до першої сотні у світових рейтингах університетів, відповідно до переліку, визначеного Кабінетом Міністрів України;

4) іноземні працівники творчих професій;

5) іноземні IT-професіонали [11].

Висновки. Отже, захист трудових прав мігрантів знаходить своє вираження одразу у декількох формах та рівнях правового регулювання. Iї цеглинами, будівними елементами $€$ закріплені в законодавчих актах гарантії трудових прав усіх категорій працівників, а також іноземців-мігрантів безпосередньо. Реалізація цих гарантій відбувається через спеціальний юридичний механізм, який об'єднує загальні та особливі норми права, які встановлюють базові аспекти регламенту трудових правовідносин, a також правовідносин, пов'язаних iз працею безпосередньо мігрантів. Наведені аспекти дають можливість відзначити, що захист трудових прав мігрантів - це особливий правовий режим, який базується на закріплених у Конституції та законах України гарантіях праці та державного забезпечення трудових прав усіх категорій працівників, у тому числі мігрантів, виражений у спеціальному наборі процедурних заходів, засобів та способів реалізації правових норм, які спрямовані на забезпечення всіх законних можливостей мігрантів у сфері трудового права, а також при- тягнення за потреби порушників цих можливостей до відповідальності.

Aктуальність статmі полягае в тому, що юридичні можливості людини на території будь-якої держави залежать від декількох факторів, серед яких слід назвати ступінь нормативного регулювання прав людини, місце права в системі регулювання суспільних відносин, а також ставлення держави до питання непорушності правового статусу людини й громадянина. На нашу думку, останній момент постае найбільш важливим, адже фактично йдеться про захист із боку держави законних інтересів кожного індивіда. Крім того, особливо гостро питання захисту юридичних можливостей постає щодо суб’єктів, які перебувають у «груnі ризику», тобто їх правовий статус має складний, іноді невизначений або навіть спірний характер. Саме такими суб'єктами сьогодні є мігранти. Внаслідок особливостей свого правового статусу представники циєё соціально-правової групи потребують захисту прав, зокрема, у трудовій галузі. У статmі з огляду на аналіз наукових поглядів учених наведено концептуальні підходи до визначення змісту поняття «правовий захист». Сформульовано власне розуміння сутності правового захисту трудових прав мігрантів як окремої категорії працівників. Аргументовано, що захист трудових прав мігрантів виражається у спеціальному наборі проиедурних заходів, засобів та способів реалізації правових норм, які спрямовані на забезпечення всіх законних можливостей мігрантів у сфері трудового права. Визначено, щзо держава в особі уповноважених органів державної влади здійснюе контроль у сфері праці, метою якого є забезпечення законності, а також непорушності ключових прав та свобод людини й громадя- 
нина. Зокрема, праця будь-якої особи без належного оформлення, тобто без укладання з нею трудового договору, у тому числі мігранта, є серйозним порушенням трудового законодавства. Фактично така праия є «тіньовою», у зв'язку з чим працівник, наприклад, іноземець, який працюе на підприємстві чи в організациї, не має статусу працуівника, шуо, зрештою, може обмежити його можливості у користуванні передбаченими законодавством гарантіями у сфері праці.

Ключові слова: трудові права, мігранти, правовий захист, захист трудових прав.

Kozin S. The essence and features of protection of labor rights of migrants

The relevance of the article is that the legal capacity of man in any state depends on several factors, including the degree of regulation of human rights, the place of law in the system of regulation of public relations, as well as the state's attitude to the inviolability of legal status. In our opinion, the last moment is the most important, because it is actually about the protection of the legitimate interests of each individual by the state. In addition, the issue of protection of legal opportunities is particularly acute in relation to entities that are in the "risk group", i.e., their legal status is complex, at times, uncertain or even controversial. Such subjects are migrants today. Due to the peculiarities of their legal status, the representatives of this socio-legal group need protection of rights, in particular, in the labor sector. The article, based on the analysis of scientific views of scientists, presents conceptual approaches to defining the meaning of the concept of "legal protection". The own understanding of the essence of legal protection of labor rights of migrants as a separate category of workers is formulated. It is argued that the protection of labor rights of migrants is expressed in a special set of procedural measures, tools and methods of implementing legal norms, which are aimed at ensuring all the legal opportunities of migrants in the field of labor law. It is determined that the state, represented by the authorized bodies of state power, exercises control in the field of labor, the purpose of which is to ensure the legality and inviolability of key human and civil rights and freedoms. In particular, the work of any person without proper registration, i.e. without concluding an employment contract with him, including a migrant, is a serious violation of labor law. In fact, such work is "shadow", due to which an employee, for example, a foreigner working in an enterprise or organization, does not have the status of an employee, which may ultimately limit his ability to use statutory guarantees in the field of labor.

Key words: labor rights, migrants, legal protection, protection of labor rights.

\section{Література}

1. Великий тлумачний словник сучасної української мови (з дод. $i$ допов.) / уклад. і голов. ред. В.Т. Бусел. Київ ; Iрпінь : ВТФ «Перун», 2005. 1728 c.

2. Тихомирова Л.В., Тихомиров М.Ю. Юридическая энциклопедия. Москва : 1997. 526 c.

3. Погрібний С.О. Механізм та принципи регулювання договірних відносин у иивільному праві України : дисертація. Київ : Київський національний університет імені Тараса Шевченка, 2009. 412 c.

4. Ромовская 3.В. Защита в советском семейном праве. Львов, 1985. 432 с.

5. Тертишніков B.I. Захист сімейних правовідносин в изивільному судочинстві. Харків, 1976. 193 с.

6. Ковальська В.В. Міліція в системі правоохоронних органів держави (адміністративно-правові аспекти) : дисертація. Київ : Київський міжнародний універcumem, 2008. 422 c. 
7. Кодекс законів про праиюю України : Кодекс від 10 грудня 1971 р. № 322-VII. Відомості Верховної Ради УРCP. 1971.

8. Про оплату праціi : Закон України віо 24 березня 1995 р. № 108/95-ВР. Відомості Верховної Ради України. 1995. № 17. Cm. 121 .

9. Про затвердження Положення про Державну службу України з питань прачі : Постанова, положення від
11 лютого 2015 р. № 96. Офіційний вісник України. 2015. № 21. Ст. 584 .

10. Деякі питання здійснення державного нагляду та контролю за додержанням законодавства про працю : Постанова, порядок від 21 серпня 2019 р. № 823. Офіиійний вісник України. 2019. № 70. Ст. 2468.

11. Про зайнятість населення Закон від 5 липня 2012 р. № 5067-VI. Відомості Верховної Ради України. 2013. № 24. Cm. 243. 